\title{
EVALUASI SEDIAAN MASKER ANTIOKSIDAN DARI EKSTRAK DAUN TEH HIJAU (CAMELLIA SINENSIS)
}

\author{
Desy Nawangsari ${ }^{1)}$, Adita Silvia ${ }^{2)}$ \\ ${ }^{1), 2)}$ Program Studi Farmasi Sekolah Tinggi Ilmu Kesehatan Harapan Bangsa Purwokerto \\ ${ }^{1)}$ Desynawangsari@shb.ac.id, ${ }^{2)}$ aditasilvia@shb.ac.id
}

\begin{abstract}
Abstrak
Teh hijau (Camellia sinensis L.) memiliki khasiat utama sebagai antioksidan dan mengandung senyawa polifenol dalam daun teh hijau dengan komponen utama fraksi polifenol yaitu Epigallocatechin-3gallate (EGCG) yang mempunyai aktivitas kuat untuk mencegah radikal bebas yang menyebabkan penuaan dini. Telah dilakukan penelitian mengenai formulasi sediaan masker gelantioksidan yang mengandung ekstrak daun teh hijau. Penelitian diawali dengan pengujian aktivitas antioksidan ekstrak etanol daun teh hijau dengan metode reduksi radikal bebas larutan 1,1-difenil-2-pikrilhidrazil menggunakan spektrofotometri sinar tampak. Pengujian aktivitas antioksidan menunjukkan bahwa ekstrak etanol daun teh hijau memberikan nilai IC50 sebesar 3,17 $\mu \mathrm{g} / \mathrm{mL}$. Formulasi sediaan masker gel yang dibuat yaitu F0 (basis tanpa zat aktif), F1 (basis + konsentrasi ekstrak etanol daun teh hijau seharga IC50 (0,000317\%)), F2 (basis + konsentrasi ekstrak etanol daun teh hijau seharga 50xIC50 $(0,0158 \%)$ ), F3 (basis + konsentrasi ekstrak etanol daun teh hijau seharga 100xIC50(0,0317\%)), F4 (basis + konsentrasi ekstrak etanol daun teh hijau seharga IC50), F5 ( basis + konsentrasi ekstrak etanol daun teh hijau seharga IC50), F6 (basis + konsentrasi ekstrak etanol daun teh hijau seharga IC50. Evaluasi sediaan masker gel meliputi, pemeriksaan organoleptis dan homogenitas, pH,viskositas, waktu kering sediaan dan pengujian stabilitas antioksidan. F2 memberikan aktivitas peredaman radikal bebas yang baik dan lebih tinggi dari produk yang ada di pasaran. F4, F5, F6 menunjukkan peningkatan aktivitas peredaman radikal bebas.
\end{abstract}

Kata kunci : Daun teh hijau (Camellia sinensis L.), DPPh, IC50 masker gel.

\begin{abstract}
Green tea (Camellia sinensis L.) has the main efficacy as an antioxidant and contains polyphenol compounds in green tea leaves with the main component of polyphenol fraction namely Epigallocatechin-3-gallate $(E G C G)$ which has strong activity to prevent free radicals that cause premature aging. Research has been carried out on the formulation of maskantioxidant preparations containing green tea leaf extract. The study begins with testing the antioxidant activity of ethanol extract of green tea leaves with a free radical reduction method of 1,1-diphenyl-2-picrylhydrazyl using visible spectrophotometry. Testing of antioxidant activity showed that the ethanol extract of green tea leaves gave an IC50 value of $3.17 \mu \mathrm{g} / \mathrm{mL}$. Formulations of gel masks made were FO (base without active substances), F1 (base + concentration of ethanol extract of green tea leaves for IC50 (0,000317\%)), F2 (base + concentration of ethanol extract of green tea leaves for 50xIC50 (0, 0158\%)), F3 (base + concentration of ethanol extract of green tea leaves for 100xIC50 $(0.0317 \%)), F 4$ (base + concentration of ethanol extract of green tea leaves for IC50), F5 (base + concentration of ethanol extract of green tea leaves worth IC50), F6 (base + concentration of ethanol extract of green tea leaves for IC50. Evaluation of gel mask preparations include, organoleptic examination and homogeneity,

pH, viscosity, dry time of preparation and testing of antioxidant stability. F2 provides better and higher free radical reduction activity than products on the market. F4, F5, F6 shows an increase in free radical reduction activity.
\end{abstract}

Keywords: Green tea leaves (Camellia sinensis L.), DPPh, IC50 gel mask. 


\section{PENDAHULUAN}

Kulit adalah organ tubuh yang merupakan permukaan luar organisme dan membatasi lingkungan dalam tubuh dengan lingkungan luar. Kulit berfungsi untuk melindungi jaringan terhadap kerusakan kimia dan fisika, terutama kerusakan mekanik dan terhadap masuknya mikroorganisme. (Setiadi, 2007) Kulit secara alami dapat mengalami penuaaan dini dan hal ini dapat disebabkan oleh sumber radikal bebas yang berasal dari lingkungan seperti polusi udara, sinar matahari, gesekan mekanik, suhu panas atau dingin dan reaksi oksidasi yang berlebihan yang dapat menyebabkan reaksi oksidatif seperti kerusakan atau kematian sel (Mutchler, 1991).

Tubuh manusia memiliki sistem antioksidan untuk mengenal reaktivitas radikal bebas, yang secara berkelanjutan dibentuk sendiri oleh tubuh. Tetapi dalam keadaan tertentu tubuh tidak dapat mengatasinya sendiri sehingga tubuh memerlukan zat-zat antioksidan dari luar tubuh untuk mencegah terjadinya reaksi reaktif radikal bebas tersebut. Antioksidan merupakan senyawa yang mampu menangkal atau meredam dampak negatif oksidan dalam tubuh, yang bekerja dengan cara mendonorkan satu elektronnya kepada senyawa yang bersifat oksidan sehingga aktivitas senyawa oksidan tersebut dapat dihambat. (Winarsi, 2007) Salah satu contoh zat antioksidan yang dibentuk oleh tubuh sendiri adalah cysteine, glutathione dan Dpenicillamin sedangkan yang berasal dari luar tubuh salah satu contohnya dapat diperoleh dari teh dan madu. (Youngson, 2003).

Salah satu penangkap efek buruk dari radikal bebas adalah senyawa antioksidan. Teh hijau merupakan bahan alami yang banyak digunakan dalam industry makanan maupun industry kosmetik. Tumbuhan ini banyak di gemari karena teh hijau memiliki kandungan polifenol dan tanin yang cukup tinggi, sehingga banyak digunakan sebagai penangkal radikal bebas (Tranggono, 2009).

Daun teh mengandung 30-40 \% polifenol yang sebagian besar dikenal dengan katekin. Komposisi daun teh terkenal sangat kompleks. Lebih dari 400 komponen kimiawi telah diidentifikasi dalam daun teh. Jumlah komponen kimiawi ini berbeda-beda tergantung pada tanah, iklim, dan usia daun teh ketika dipetik. Katekin (polifenol) adalah antioksidan yang kuat, lebih kuat daripada vitamin $\mathrm{E}, \mathrm{C}$ dan ß-karoten. Di dalam teh terdapat beberapa jenis katekin yaitu epikatekin (EC), epikatekin galat (ECG), epigallokatekin 
(EGC), epigalokatekin galat (EGCG), gallokatekin dan katekin (Syah, 2006).

Masker wajah gel memiliki beberapa manfaat diantaranya mampu merileksasikan otot-otot wajah, membersihkan, menyegarkan, melembabkan, dan melembutkan kulit wajah (Vieira, 2009). Masker bentuk gel juga mempunyai beberapa keuntungandiantaranya penggunaan yang mudah, serta mudah untuk dibilas dan di bersihkan. Selain itu, dapat juga diangkat atau dilepaskan seperti membran elastis (Harry,1973).

Berdasarkan penelitian yang telah dilakukan sebelumnya (Faramayuda, 2003) diketahui bahwa pada daun teh hijau memiliki efek antioksidan yang baik yang dapat menangkal efek radikal bebas pada kulit. Maksud dan tujuan penelitian ini adalah untuk mengetahui stabilitas antioksidan ekstrak etanol daun teh hijau dalam sediaan masker gel.

\section{METODOLOGI}

\section{A. Metode Penelitian \\ 1. Bahan}

Ekstrak etanol daun teh hijau, Polivinil Alkohol (PVA), Hidroksi Propil Metil Selulosa (HPMC), metil paraben, propil paraben, etanol 96\% v/v, propilen glikol,
DPPH, metanol p.a, produk pembanding dan air suling.

\section{Metode}

Penelitian dilakukan dalam beberapa tahap yaitu penyiapan dan pengumpulan bahan segar daun teh hijau (Camellia sinensis L.), ekstraksi, penapisan fitokimia, pemeriksaan karakteristik simplisia, pengujian aktivitas antioksidan secara kualitatif ekstrak etanol daun teh hijau, pemeriksaan daun teh hijau, uji aktivitas antioksidan ekstrak etanol daun teh hijau, penentuan IC50, pemeriksaan bahan baku sediaan masker gel, pembuatan formula sediaan masker gel dan evaluasi sediaan masker gel.

Daun teh hijau diperoleh dari perkebunan Kaligua, Bumiayu Jawa Tengah. Untuk metode ekstraksi dilakukan dengan cara soxhlet menggunakan pelarut etanol 96\%v/v. Penapisan fitokimia dilakukan terhadap simplisia dan ekstrak etanol daun teh hijau. Dilanjutkan dengan pengujian aktivitas antioksidan secara kualitatif terhadap ekstrak etanol daun teh hijau. Pemeriksaan karakteristik simplisia meliputi pemeriksaan makroskopik, mikroskopik, penentuan kadar abu total, penentuan kadar abu larut air, penentuan 
kadar abu tidak larut asam, penentuan kadar sari larut etanol dan larut air dan penentuan kadar air.

Pemeriksaan bahan baku untuk pembuatan basis gel berdasarkan Farmakope Indonesia edisi IV (Depkes, 1995) dan Handbook of Pharmaceutical Excipients edisi IV meliputi organoleptis dan kelarutan. Tujuannya untuk mengetahui kualitas dan karakteristik bahan baku yang akan digunakan pada saat formulasi.

Formulasi sediaan masker gel dibuat menjadi 7 formula yaitu F0 berupa basis tanpa zat aktif, F1 berupa basis dan konsentrasi ekstrak etanol daun teh hijau seharga IC50 F2 berupa basis dan konsentrasi ekstrak etanol daun teh hijau seharga 50 kali IC50 F3 berupa basis dan konsentrasi ekstrak etanol daun teh hijau jangka waktu 28 hari.

Tabel 1. Formulasi Sediaan Masker Gel seharga 100 kali IC5, F4 berupa basis dan konsentrasi ekstrak etanol daun teh hijau seharga IC50, F5 berupa basis dengan konsentrasi ekstrak etanol daun teh hijau seharga IC50, F6 berupa basis dan konsentrasi ekstrak etanol daun teh hijau seharga IC50. Formulasi sediaan masker gel dapat dilihat pada Tabel 1.

Evaluasi sediaan masker gel meliputi uji organoleptis dan homogenitas, uji pH, uji viskositas dan pengujian kestabilan antioksidan sediaan. Penentuan kestabilan antioksidan masker gel dilakukan dengan menguji aktivitas peredaman radikal bebas DPPH oleh sediaan masker gel dengan menggunakan spektrofotometri uvvisible pada panjang gelombang max DPPH $515516 \mathrm{~nm}$, dan diuji setiap 7 hari selama

\begin{tabular}{|c|c|c|c|c|c|c|c|}
\hline \multirow[t]{2}{*}{ Bahan } & \multicolumn{7}{|c|}{ Formula (Gram) } \\
\hline & F0 & F1 & F2 & F3 & $\mathrm{F} 4$ & F5 & F6 \\
\hline $\begin{array}{l}\text { Ekstrak daun teh } \\
\text { hijau }\end{array}$ & - & $0,000317 \%$ & $0,0158 \%$ & $0,0317 \%$ & $0,00031 \%$ & $0,00031 \%$ & $0,00031 \%$ \\
\hline $\begin{array}{l}\text { Hidroksi Propil } \\
\text { Metil Selulosa } \\
\text { (HPMC) }\end{array}$ & 10 & 10 & 10 & 10 & 10 & 10 & 10 \\
\hline Propilenglikol & 10 & 10 & 10 & 10 & 10 & 10 & 10 \\
\hline Metil Paraben & 0,15 & 0,15 & 0,15 & 0,15 & 0,15 & 0,15 & 0,15 \\
\hline Propil Paraben & 0,15 & 0,15 & 0,15 & 0,15 & 0,15 & 0,15 & 0,15 \\
\hline Etanol $96 \%$ v/v & 15 & 15 & 15 & 15 & 15 & 15 & 15 \\
\hline Air Suling ad & 100 & 100 & 100 & 100 & 100 & 100 & 100 \\
\hline
\end{tabular}




\section{HASIL DAN PEMBAHASAN}

Pada penelitian ini dibuat sediaan masker gel antioksidan. Bahan berkhasiat yang digunakan adalah daun teh hijau. Pengumpulan simplisia daun teh hijau diperoleh dari perkebunan Kertamanah yang berada di daerah Pangalengan, Jawa Barat pada bulan September tahun 2018.

Pada penelitian sebelumnya telah dibuat formulasi sediaan dengan menggunakan ekstrak daun teh hijau sebagai antioksidan dalam berbagai sediaan seperti lotion dan krim. Kali ini penelitian dilakukan dengan pembuatan formulasi sediaan masker gel ekstrak daun teh hijau . Berdasarkan penapisan fitokimia daun teh hijau memiliki senyawa polifenol yang berkhasiat sebagai antioksidan dan merupakan komponen terbesar yang dikandungnya. Adanya senyawa polifenol ditandai dengan adanya perubahan warna dari kuning menjadi biru hitam akibat terjadinya reaksi antara gugus fenol dengan larutan besi (III) klorida. Penapisan fitokimia dilakukan dengan tujuan untuk mengetahui kandungan senyawa metabolit sekunder yang terkandung dalam simplisia yang berkaitan dengan khasiat atau aktivitas farmakologinya.

Pada proses ekstraksi daun teh hijau digunakan metode ekstraksi panas dengan alat soxhlet menggunakan pelarut etanol 96\%v/v. Pemanasan dilakukan pada suhu $70-80^{\circ} \mathrm{C}$ selama 3 hari. Proses ekstraksi dilakukan hingga serbuk simplisia tersari sempurna yang ditandai dengan jernihnya pelarut yang menetes dari kondensor kelabu alas bulat. Ekstrak cair yang diperoleh kemudian dikentalkan dengan rotavapor sehingga bebas pelarut dan dipekatkan pada tangas air hingga diperoleh ekstrak kental. Diperoleh persen rendemen sebesar $24,0735 \%$.

Penetapan karakteristik simplisia meliputi pemeriksaan makroskopik, pemeriksaan mikroskopik, penetapan kadar abu, penetapan kadar sari larut etanol, penetapan kadar sari larut air dan penetapan kadar air. Secara umum, penetapan ini dilakukan untuk mengetahui batasan atau standarisasi bahan dan mengetahui kriteria umum kualitas bahan yang akan digunakan.

$$
\text { Pemeriksaan makroskopik }
$$
dilakukan untuk mengetahui kebenaran simplisia yang sesuai dengan pustaka sedangkan pemeriksaan mikroskopik terhadap serbuk kasar simplisia untuk mencari ciri spesifik yang dapat digunakan sebagai identitas tanaman. Penetapan kadar abu total dilakukan untuk mengetahui kandungan mineral yang terkandung di dalam simplisia. Berdasarkan pemeriksaan, 
diperoleh kadar abu total sebesar 4,94\%b/b. Ini menunjukkan kandungan mineral dalam simplisia daun teh hijau memenuhi dari yang dipersyaratkan yaitu $=7 \% \mathrm{~b} / \mathrm{b}$. Penetapan kadar sari larut air dan kadar sari larut etanol dilakukan untuk mengetahui jumlah senyawa yang larut dalam air dan etanol. Berdasarkan pemeriksaan diperoleh kadar sari larut air sebesar 30,21\%b/b dan kadar sari larut etanol sebesar 27,66\%b/b. Ini menunjukkan bahwa daun teh hijau lebih banyak tersari dalam pelarut air. Penetapan kadar air dilakukan untuk mengetahui kandungan air pada simplisia. Kadar air yang berlebih pada simplisia dapat menyebabkan terjadinya pertumbuhan mikroba, jamur, reaksi enzimatis atau proses hidrolisis. Berdasarkan pemeriksaan diperoleh kadar air sebesar 3,00\%v/b. Ini menunjukkan kadar air dalam simplisia memenuhi dari yang dipersyaratkan yaitu $=10 \%$. Penetapan kadar air dilakukan dengan cara destilasi menggunakan pelarut toluen yang telah dijenuhkan terlebih dahulu dengan air selama 24 jam. Hal tersebut dimaksudkan agar pada saat destilasi, toluen yang digunakan tidak mengikat air yang terkandung dalam simplisia, sehingga persen kadar air yang dihasilkan akurat.
Pemeriksaan bahan baku yang akan digunakan dalam pembuatan basis masker gel dilakukan untuk memastikan bahwa bahan baku yang digunakan sesuai dengan standarisasi bahan dan mengetahui kualitas bahan yang akan digunakan. Pemeriksaan meliputi organoleptis dan kelarutan terhadap polivinil alkohol, Hidroksi Propil Metil Selulosa, propilen glikol, metil paraben, propil paraben dan etanol 96\% v/v dan air suling. (Ansel, 1989)

Pengujian aktivitas antioksidan dilakukan dengan menggunakan instrumen spektrofotometri uv-visible terhadap ekstrak yang didasarkan pada kemampuannya untuk menangkap radikal bebas DPPH. Pengujian ini dilakukan dengan mengukur penurunan serapan DPPH pada panjang gelombang maksimum 516,0 $\mathrm{nm}$ setelah direaksikan dengan larutan uji yaitu ekstrak etanol daun teh hijau dengan berbagai konsentrasi. Hasil reaksi antara larutan pereaksi DPPH dengan larutan uji ekstrak etanol daun teh hijau menunjukkan perubahan warna dari ungu menjadi kuning, dimana $\mathrm{H}+$ merupakan atom hidrogen yang mengandung satu proton dan satu elektron yang berasal dari senyawa peredam radikal bebas yang akan bereaksi dengan DPPH membentuk senyawa DPPHidrazin yang stabil. 
Kemampuan antioksidan untuk tunggal polivinil alkohol. Dilakukan meredam radikal bebas dinyatakan dengan percobaan kembali dengan menggunakan IC50 yang dihitung dari persamaan regresi basis tunggal Hidroksi Propil Metil linier antara konsentarsi larutan uji dengan Selulosa. Berdasarkan percobaan ini persen peredaman dimana hubungannya diperoleh persen peredaman dengan berbanding lurus yaitu semakin tinggi stabilitas yang baik.

konsentrasi zat uji maka semakin tinggi pula persen peredaman. IC50 merupakan konsentrasi efektif larutan uji yang diperlukan untuk menurunkan 50\% intensitas dibandingkan larutan pereaksi. Berdasarkan pengujian, IC50 dari ekstrak etanol daun teh hijau sebesar $3,17 \mu \mathrm{g} / \mathrm{mL}$.

Pada pembuatan sediaan masker gel digunakan basis polivinil alkohol, metil paraben, propil paraben, propilen glikol, etanol $96 \% \mathrm{v} / \mathrm{v}$ dan air suling.

Pada pembuatan sediaan dengan basis polivinil alkohol, sediaan memiliki kelebihan diantaranya tekstur gel lembut dan elastis setelah penggunaan. Namun, pada pengujian stabilitas antioksidan, sediaan menghasilkan persen peredaman yang tidak sesuai dengan yang diharapkan oleh karena itu dilakukan percobaan kembali dengan menggunakan basis campuran polivinil alkohol dan Hidroksi Propil Metil Selulosa (6 : 4). Setelah dilakukan pembuatan sediaan dengan menggunakan basis ini, persen peredaman Formulasi sediaan masker gel dibuat menjadi 7 formula yaitu F0 berupa basis tanpa zat aktif, F1 berupa basis dan konsentrasi ekstrak etanol daun teh hijau

seharga IC50, F2 berupa basis dan konsentrasi ekstrak etanol daun teh hijau seharga 50 kali IC50, F3 berupa basis dan konsentrasi ekstrak etanol daun teh hijau seharga 100 kali IC50, F4 berupa basis dan konsentrasi ekstrak etanol daun teh hijau seharga IC50, F5 berupa basis dengan konsentrasi ekstrak etanol daun teh hijau seharga IC50, F6 berupa basis dan konsentrasi ekstrak etanol daun teh hijau seharga IC50.

Pada formulasi sediaan, dibuat 3 formulasi dengan kombinasi zat aktif yaitu ekstrak etanol daun teh hijau dengan beberapa konsentrasi madu.

Tujuan kombinasi antara ekstrak etanol daun teh hijau untuk mengetahui pengaruh penambahan madu hitam sebagai antioksidan terhadap persen peredaman radikal bebas. Hasil pengukuran persen menunjukkan hasil yang sama dengan basis 
peredaman sediaan masker gel dapat dilihat pada Tabel 2.

Berdasarkan percobaan, formulasi sediaan dengan basis HPMC tanpa zat aktif (F0) menunjukkan persen peredaman berturutturut hingga minggu keempat sebesar $21,82 \%, 21,58 \%, 22,73 \%, 21,81 \%$, 21,46.\%. Formulasi F1, F2, F3, menunjukkan peningkatan persen peredaman radikal bebas dibandingkan terhadap F0 dengan stabilitas yang baik. Hal ini menunjukkan ekstrak etanol daun teh hijau memiliki aktivitas antioksidan yang baik. Formulasi F4, F5, F6, menunjukkan peningkatan persen peredaman radikal bebas dibandingkan terhadap F1 dengan stabilitas yang baik. Berdasarkan hasil perbandingan formulasi sediaan masker gel yang dibuat dengan produk yang ada di pasaran, F2 menunjukkan persen peredaman yang lebih tinggi dibandingkan dengan produk yang ada di pasaran. F-X atau sediaan masker gel yang ada di pasaran memiliki persen peredaman sebesar $33,59 \%$ sedangkan F2 memiliki persen peredaman sebesar $71,98 \%$.
Hasil evaluasi organoleptis menunjukan, bahwa formulasi sediaan basis (F0) dan formulasi sediaan yang mengandung ekstrak etanol teh hijau (F1, F2, dan F3, F4, F5, F6) memiliki homogenitas yang baik. Bau dan warna tidak mengalami perubahan selama 28 hari penyimpanan. Hal ini menunjukkan bahwa sediaan masker gel stabil selama penyimpanan.

Pengukuran viskositas dilakukan pada hari ke $0,7,14,21$, dan 28 . Berdasarkan hasil pengamatan setiap formulasi sediaan menunjukkan viskositas yang stabil dan baik selama penyimpanan. Pengukuran viskositas dengan menggunakan spindel R6.

Pengukuran $\mathrm{pH}$ dilakukan pada hari ke $0,7,14,21$, dan 28. Berdasarkan hasil pengamatan, setiap formulasi sediaan menunjukkan $\mathrm{pH}$ yang stabil selama penyimpanan dengan rentang $\mathrm{pH}$ yang aman untuk pemakaian yaitu $\mathrm{pH} 4-7$. Nilai pH pada hari ke 28 dari F0 sebesar 5,48, F1 sebesar 5,35, F2 sebesar 5,94, F3 sebesar 6,03, F4 sebesar 5,84, F5 sebesar 5,65 dan F6 sebesar 5,66. 
Tabel 2. Pengukuran Persen Peredaman Sediaan Masker Gel

\begin{tabular}{|c|c|c|c|c|c|}
\hline Formula & \multicolumn{5}{|c|}{ \% Peredaman } \\
\hline & Hari ke-0 & Hari ke-7 & Hari ke-14 & Hari ke-21 & Hari ke-28 \\
\hline F0 & $21,82 \pm 0,64$ & $21,58 \pm 2,23$ & $22,73 \pm 0,41$ & $21,81 \pm 0,77$ & $21,46 \pm 0,02$ \\
\hline F1 & $24,32 \pm 0,81$ & $23,79 \pm 0,64$ & $22,93 \pm 1,28$ & $23,52 \pm 0,10$ & $24,39 \pm 0,11$ \\
\hline F2 & $71,98 \pm 0,02$ & $70,95 \pm 0,04$ & $73,35 \pm 0,08$ & $72,00 \pm 0,07$ & $70,80 \pm 0,06$ \\
\hline F3 & $86,72 \pm 0,23$ & $85,83 \pm 0,03$ & $85,17 \pm 0,04$ & $89,36 \pm 0,12$ & $87,95 \pm 0,03$ \\
\hline F4 & $27,72 \pm 0,38$ & $27,02 \pm 0,30$ & $22,76 \pm 0,12$ & $31,44 \pm 0,18$ & $27,21 \pm 0,14$ \\
\hline F5 & $29,34 \pm 1,05$ & $28,53 \pm 0,38$ & $26,51 \pm 0,02$ & $28,78 \pm 0,10$ & $28,74 \pm 0,13$ \\
\hline F6 & $30,33 \pm 0,86$ & $30,26 \pm 0,73$ & $28,72 \pm 0,08$ & $28,80 \pm 0,02$ & $29,27 \pm 0,14$ \\
\hline
\end{tabular}

\section{KESIMPULAN}

1. Berdasarkan penelitian yang dilakukan ekstrak etanol daun teh hijau memiliki IC50 sebesar 3,17 $\mu \mathrm{g} / \mathrm{mL}$

2. Formula sediaan F1, F2, F3 masingmasing mengandung ekstrak sebesar $0,000317 \%, \quad 0,0158 \%, \quad 0,0317 \%$ memiliki aktivitas antioksidan yang stabilselama penyimpanan (28 hari).

3. Formulasi sediaan F4, F5, F6 yang mengandung ekstrak etanol daun teh hijau sebesar $0,000317 \%$

4. Dari tujuh formulasi sediaan yang dibuat, F2 merupakan sediaan yang paling efektif karena memiliki persen peredaman radikal bebas yang lebih tinggi dibandingkan dengan sediaan merk x yang ada di pasaran.
Diharapkan dengan adanya penelitian ini dapat menambah ilmu pengetahuan

\section{SARAN}

Diharapkan penelitian ini dapat memberikan informasi penting bahwa teh hijau dapat digunakan dalam bentuk sediaan masker gel dan dapat juga menjadi acuan bagi peniliti selanjutnya untuk mengembangkan sediaan farmasi dari ekstrak Daun teh hijau. 


\section{DAFTAR PUSTAKA}

Ansel, H.C. 1989, Pengantar Bentuk Sediaan

Farmasi, Edisi IV, Universitas Indonesia. Jakarta : 390-395, 599-600.

Departemen Kesehatan Republik Indonesia, 1995, Farmakope Indonesia IV, DepartemenKesehatan Republik Indonesia,Jakarta.

Faramayuda, F., 2003, Formulasi Sediaan Lotion Antioksidan Ekstrak Air Daun Teh Hijau (Camellia sinensis L.), Cimahi.

Mutchler, Ernst. 1991, Dinamika Obat, edisi V, terjemahan M.B Widianto dan A.S Ranti, ITB, Bandung, 577.

Setiadi. 2007, Anatomi \& Fisiologi Manusia, Graha Ilmu, Jakarta: 26.

Suranto, A. 2004, Khasiat dan Manfaat Madu Herbal, Penerbit PT. Agromedia Pustaka, Jakarta, 2.

Syah, A, A, 2006, Taklukan Penyakit Dengan teh Hijau, Penerbit PT. Agromedia Pustaka, Jakarta, 1.

Warisno, 1996, Lebah Madu, Penerbit kanisius, Yogyakarta: 46-47.

Winarsi, H. 2007, Antioksidan Alami dan Radikal Bebas, Penerbit Kanisius, Yogyakarta, 49.

Youngson, R. 2003, Antioksidan, Manfaat Vit $C \&$ E Bagi Kesehatan, Penerbit Arcan, Jakarta 